\title{
Pharmacists and COVID-19
}

\author{
Ali Elbeddini ${ }^{1 *}$ (D) Thulasika Prabaharan ${ }^{2}$, Sarah Almasalkhi ${ }^{2}$ and Cindy $\operatorname{Tran}^{2}$
}

\begin{abstract}
In the fight against COVID-19, frontline health workers have been vital to keeping the pandemic at bay, but recognition of individual professions' efforts have been inconsistent at all levels. Pharmacists around the world have continued to provide direct patient care and perform frontline duties for their communities during this pandemic, but are often relegated to the background and overlooked when frontline workers are heralded. Community pharmacists are the most accessible healthcare practitioners, which is further proven during the pandemic as they continued to provide direct patient care despite restrictions imposed by the government due to the pandemic. Due to the inaccessibility of other healthcare practitioners during this time, community pharmacists have reduced the burden on the healthcare system by diverting the influx of patients away from hospitals through triaging and screening patients. Community pharmacists have played various roles in supporting the healthcare system during COVID-19: delivering medications to patients, educating patients on telehealth services, assessing patients for renewal of chronic medications, performing consultations on minor ailments, clarifying misconceptions about COVID-19 treatments, and contributing to COVID-19 screening. Alongside ICU nurses, physicians, and respiratory therapists, hospital pharmacists have been part of the COVID-19 efforts and their roles include management of drug shortages, development of treatment protocols, participation of patient rounds, interpretation of lab results for COVID-19, participant recruitment for clinical trials, exploration of new drugs, medication management advice, and antimicrobial stewardship. Further support from pharmacists will be needed once a vaccine is launched in order to reach population-wide coverage. Amid COVID-19, pharmacists have not stopped working as frontline workers and they should be recognized as such.
\end{abstract}

Keywords: Frontline health workers, Pharmacist, COVID-19, Pandemic

\section{Introduction}

Pharmacists should have always been considered frontline workers, but especially amid COVID-19. There is no universal definition of what a frontline worker is, which leads to inconsistency on how to further classify essential workers globally during this pandemic. As a result, governments around the world have varied in how to, or whether to even recognize the work of pharmacists during the pandemic. New Zealand has provided extra remuneration for pharmacists' contributions

\footnotetext{
* Correspondence: elbeddini.a@gmail.com

'Chairman of the Pharmacy, Winchester District Memorial Hospital, 566 Louise Street, Winchester, ON KOC2KO, Canada

Full list of author information is available at the end of the article
}

amidst COVID-19, while Ontario, Canada's most populace province, has failed to include pharmacists as part of the list of frontline workers, a list that includes coworkers that many pharmacists share a place of work with. Whether in the community or hospital, pharmacists have been performing frontline roles, yet they are not universally being recognized as such.

\section{Community pharmacists amid COVID}

Pharmacists have always been the most accessible health care provider; this is especially true in the era of COVID-19. While other professionals have closed their doors to patients, community pharmacies remained open to the public despite stricter lockdown restrictions. As highly trusted healthcare clinicians, community

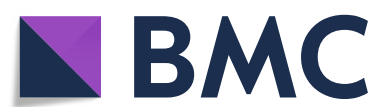

(c) The Author(s). 2020 Open Access This article is licensed under a Creative Commons Attribution 4.0 International License, which permits use, sharing, adaptation, distribution and reproduction in any medium or format, as long as you give appropriate credit to the original author(s) and the source, provide a link to the Creative Commons licence, and indicate if changes were made. The images or other third party material in this article are included in the article's Creative Commons licence, unless indicated otherwise in a credit line to the material. If material is not included in the article's Creative Commons licence and your intended use is not permitted by statutory regulation or exceeds the permitted use, you will need to obtain permission directly from the copyright holder. To view a copy of this licence, visit http://creativecommons.org/licenses/by/4.0/. The Creative Commons Public Domain Dedication waiver (http://creativecommons.org/publicdomain/zero/1.0/) applies to the data made available in this article, unless otherwise stated in a credit line to the data. 
pharmacists play a vital role in closing the gaps that are exacerbated by the additional strain on the system and reduced access to healthcare providers. For low to middle income countries, community pharmacies offer the advantage of medical advice without cost to patients who are unable to afford physician fees $[1,2]$. Despite the initial shortage of personal protective equipment, pharmacy staff continued to provide direct patient care. Pharmacies are delivering medications to patients free of charge, educating patients on telehealth services, assessing patients that require renewal of chronic medications, performing consultations on minor ailments, clarifying misconceptions about COVID-19 treatments, and contributing to COVID-19 screening [3]. Fig. 1 summarizes the key responsibilities of frontline community pharmacists. Through their triaging, community pharmacists are maximizing the efficiency of the healthcare system during this time of limited resources.

\section{Hospital pharmacists amid COVID}

The role of hospital pharmacists during this pandemic is also being overlooked by the public. Alongside ICU nurses, physicians, and respiratory therapists, hospital pharmacists contribute to COVID-19 management protocols by participating in inpatient rounds, ensuring sufficient medication supply to support ICU beds while managing critical drug shortages through the implementation of conservation strategies and sourcing alternatives [4]. Hospital pharmacists participate in antimicrobial stewardship programs; thus are directly involved in planning and responding to pathogen outbreaks, which is of heightened importance during COVID-19. As part of antimicrobial stewardship programs, hospital pharmacists have been involved in developing local treatment protocols that repurpose antivirals and monitoring the use of antibiotics in cases of bacterial co-infections in COVID-19 patients [5]. In addition, pharmacists can help interpret test results for COVID19, explore new drug therapies or uses, and provide medication management recommendations to their colleagues [6]. While there is no current cure for COVID19, potential treatment options like hydroxychloroquine, methylprednisolone, and remdesivir are being evaluated in clinical trials [6]. Hospital pharmacists can help with the enrolment of infected patients for these types of studies [6]. Fig. 2 describes the key roles of frontline hospital pharmacists. Because of various roles hospital pharmacists play in the effort against COVID-19, they are constantly exposed to the virus. However, they manage to complete their responsibilities similarly to their co-workers without the same recognition as frontline workers.

\section{The future role of pharmacists amid COVID}

Looking forward, pharmacists' medication expertise should be leveraged in vaccine development and clinical

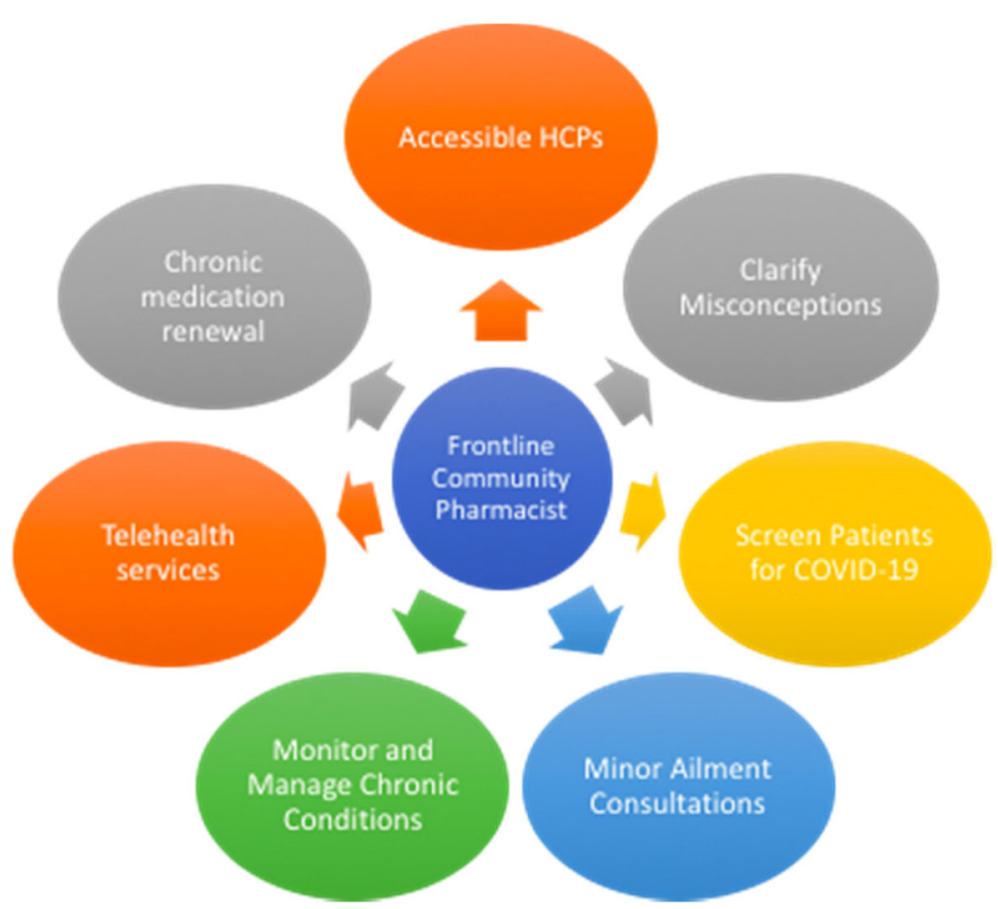

Fig. 1 Key Responsibilities of Frontline Community Pharmacists amid COVID-19 


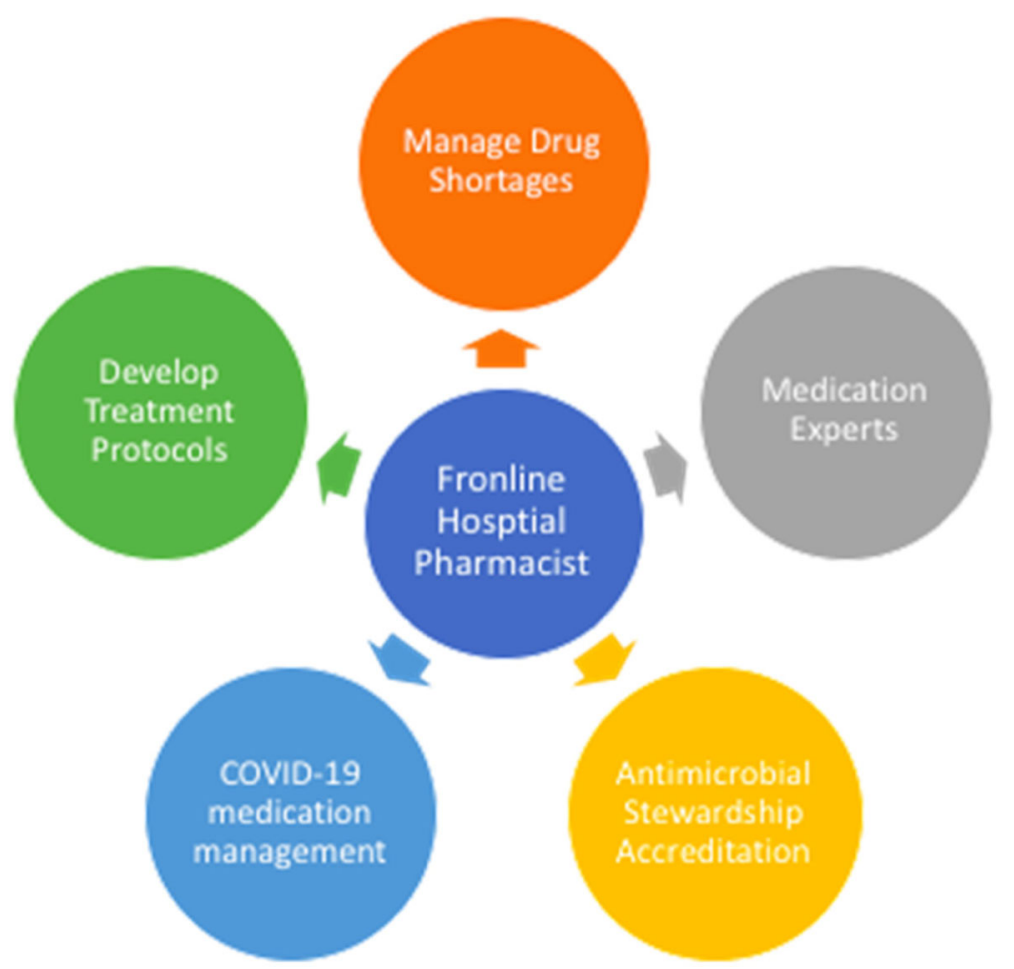

Fig. 2 Key Responsibilities of Hospital Pharmacists amid COVID-19

trials. When the vaccine against COVID-19 is available, pharmacists will be considered one of the frontline health workers that should be permitted to give immunizations. Given the past success of community pharmacists with increasing annual seasonal influenza uptake and their accessibility, pharmacists will need to be central in administering COVID-19 vaccines in order to achieve rapid population-wide coverage. Furthermore, screening and testing patients for COVID-19 are both crucial interventions to flatten the curve. Pharmacists in Alberta are screening patients daily and referring them to nearest testing facilities [7]. While American pharmacists may order and administer FDA-approved tests [8]. Increasing the accessibility of testing is imperative if countries wish to escape lockdowns.

\section{Conclusion}

In the fight against COVID-19, our shield is the healthcare system and our soldiers, healthcare professionals, which undoubtedly include pharmacists. Pharmacists have not stopped working because of COVID-19 and in fact, have stepped up to take on more responsibilities. Their efforts should not be forgotten when frontline workers are lauded once this global pandemic ends, but without question, should not be overlooked in the present, when their frontline efforts are still needed to fight COVID-19. Pharmacists are frontline workers; they should be addressed as such and given the recognition they deserve.

\section{Acknowledgements}

I would like to acknowledge the support from the pharmacy team in facilitating the data collection.

\section{Authors' contributions}

Ali Elbeddini (primary and corresponding author): Original Manuscript preparation, Conceptualization, Data curation, Analysis of the paper, Literature search, Data collection, Writing, Reviewing and Editing, Driving for the ideas and thoughts. Sarah Almasalkhi, Original Manuscript preparation, Analysis of the paper, Literature search, Data collection, Writing, Reviewing and Editing, Driving for the ideas and thoughts. Thulasika Prabaharan,

Original Manuscript preparation, Analysis of the paper, Literature search, Data collection, curation, Writing, Reviewing and Editing, Driving for the ideas and thoughts. Cindy Tran, Original Manuscript preparation, Analysis of the paper, Literature search, Data collection, Writing, Reviewing and Editing, Driving for the ideas and thoughts. The authors read and approved the final manuscript

\section{Funding}

I know of no conflict of interest with this publication, and there has been no. financial support for this work that could have influenced the outcome.

\section{Availability of data and materials}

Data sharing does not apply to this article as no datasets were generated or analyzed during the current study.

Competing interests

No known competing interest to declare. 


\section{Author details}

'Chairman of the Pharmacy, Winchester District Memorial Hospital, 566 Louise Street, Winchester, ON KOC2KO, Canada. 'Leslie Dan Faculty of

Pharmacy, University of Toronto, 144 college st, Toronto M5S 3M2, Canada.

Received: 26 May 2020 Accepted: 11 June 2020

Published online: 19 June 2020

\section{References}

1. Bukhari N, Rasheed H, Nayyer B, Babar Z-U-D. Pharmacists at the frontline beating the COVID-19 pandemic. J Pharm Policy Pract. 2020 Dec;13(1).

2. Office of the Premier. Newsroom: Pandemic Pay Provides Support for Frontline Workers Fighting COVID-19. 2020; Available from: https://news. ontario.ca/opo/en/2020/04/pandemic-pay-provides-support-for-frontlineworkers-fighting-covid-19.html [cited 202019 May].

3. CVS Health. COVID-19 testing: Information and locations [Internet]. 2020. Available from: https://cvshealth.com/covid-19/testing-information-locations [cited 202019 May].

4. Yau S. Recognition of hospital pharmacists and pharmacy technicians, as frontline workers eligible for pandemic pay during COVID-19. 2020.

5. Stevens MP, Patel PK, Nori P. Involving antimicrobial stewardship programs in COVID-19 response efforts: all hands on deck. Infect Control Hosp Epidemiol. 2020:1-2.

6. Al-Quteimat OM, Amer AM. SARS-CoV-2 outbreak: how can pharmacists help? Res Soc Adm Pharm. 2020;51551-7411(20):30238-2.

7. Mertz E. Pharmacists get billing code to screen Albertans for COVID-19: asked to limit drug supplies [Internet]. Global News. 2020. Available from: https://globalnews.ca/news/6703187/pharmacists-screen-coronavirusalberta-health-drug-supply/ [cited 202024 May].

8. Pharmacists provide Covid-19 testing. [Internet]. Globe and Mail. 2020. Available from: https://www.theglobeandmail.com/canada/article-the-lateston-the-coronavirus-ontario-to-reveal-stark-projections/ [cited 202024 May].

\section{Publisher's Note}

Springer Nature remains neutral with regard to jurisdictional claims in published maps and institutional affiliations.

\section{Ready to submit your research? Choose BMC and benefit from:}

- fast, convenient online submission

- thorough peer review by experienced researchers in your field

- rapid publication on acceptance

- support for research data, including large and complex data types

- gold Open Access which fosters wider collaboration and increased citations

- maximum visibility for your research: over $100 \mathrm{M}$ website views per year

At $\mathrm{BMC}$, research is always in progress.

Learn more biomedcentral.com/submissions 